\title{
Possible changes in spatial distribution of walnut (Juglans regia L.) in Europe under warming climate
}

\author{
Sonia Paź-Dyderska ${ }^{1}$ (D) Andrzej M. Jagodziński ${ }^{1,2}$ (D) Marcin K. Dyderski ${ }^{1}$ (D)
}

Received: 7 September 2019 / Accepted: 29 December 2020 / Published online: 1 February 2021

(C) The Author(s) 2021

\begin{abstract}
Juglans regia $\mathrm{L}$. is a species of great importance for environmental management due to attractive wood and nutritious fruits, but also high invasive potential. Thus, uncertainties connected with its range shift are essential for environmental management. We aimed to predict the future climatic optimum of J. regia in Europe under changing climate, to assess the most important climatic factors that determine its potential distribution, and to compare the results obtained among three different global circulation models (GCMs). We used distribution data from the Global Biodiversity Information Facility and completed it with data from the literature. Using the MaxEnt algorithm, we prepared a species distribution model for the years 2061-2080 using 19 bioclimatic variables. We applied three emission scenarios, expressed by representative concentration pathways (RCPs): RCP2.6, RCP4.5, and RCP8.5 and three GCMs: HadGEM2-ES, IPSL-CM5A-LR, and MPI-SM-LR. Our study predicted northward shift of the species, with simultaneous distribution loss at the southern edge of the current range, driven by increasing climate seasonality. Temperature seasonality and temperature annual range were the predictors of highest importance. General trends are common for the projections presented, but the variability of our projections among the GCMs or RCPs applied (predicted range will contract from 17.4 to $84.6 \%$ of the current distribution area) shows that caution should be maintained while managing $J$. regia populations. Adaptive measures should focus on maintaining genetic resources and assisted migration at the southern range edge, due to range contraction. Simultaneously, at the northern edge of the range, J. regia turns into an invasive species, which may need risk assessments and control of unintended spread.
\end{abstract}

Keywords Habitat suitability $\cdot$ English walnut $\cdot$ Species distribution model $\cdot$ Invasive tree $\cdot$ Bioclimatic model $\cdot$ Agroforestry

\section{Introduction}

Climate is one of the most important factors determining species ranges (Pearson and Dawson 2003; Hickler et al. 2012; Scheffers et al. 2016). For that reason, global climatic changes indicate the emerging need for further research to assess possible consequences in diverse ecosystems and shifts of particular species distributions (Walther 2010; Thuiller et al. 2011). Increasing temperature and decreasing precipitation

Communicated by Ülo Mander

Marcin K. Dyderski

mdyderski@man.poznan.pl

1 Institute of Dendrology, Polish Academy of Sciences, Parkowa 5, 62-035 Kórnik, Poland

2 Department of Game Management and Forest Protection, Faculty of Forestry and Wood Technology, Poznań University of Life Sciences, Wojska Polskiego 71c, 60-625 Poznań, Poland contribute to the escalation of the negative effects of climate change (Peng et al. 2004; Davidson and Janssens 2006). These are strongly connected not only with biological diversity (Thuiller et al. 2011; Scheffers et al. 2016) but also with the economy and well-being of humankind (McMichael et al. 2006; Schmidhuber and Tubiello 2007). Although climate change mostly threatens rare and specialized species, usually with small extents of natural distribution (Czortek et al. 2018; Walas et al. 2019), even widely dispersed species, constituting the basis of management, seem to be endangered (Sykes and Prentice 1996; Dyderski et al. 2018; Thurm et al. 2018).

Climate change affecting tree species distributions is a good example of the wide magnitude of global changes (McKenney et al. 2007; Kremer et al. 2012). From the physiological point of view, higher $\mathrm{CO}_{2}$ concentration increases the efficiency of photosynthesis $\mathrm{C} 3$ species, which is the most widespread in transitional climates (Kozlowski and Pallardy 1997) and accelerates biomass production (Hobbie and Chapin 1998; Liberloo et al. 2006). More recent papers also 
predict increase of primary production and annual volume increments of trees, or even increased drought resistance (Lindner et al. 2014). However, this effect will quickly subside due to increased evapotranspiration. Moreover, increased rates of tree growth will result in shorter lifespans (Büntgen et al. 2019) and increased mortality caused by accelerated competition for light resources (Luo et al. 2019). Dynamic decreases of favorable conditions, intensified by catastrophic winds, extensive fires, or insect outbreaks (Seidl et al. 2014), can easily lead to decline of number of species and growth of prices of wood used to make paper and furniture or fruits at the same time (Hertin et al. 2003), as well as to decrease economic value of forests (Hanewinkel et al. 2013).

Another undesirable mechanism caused by climate change is the increasing number of invasive species (Thuiller et al. 2007; Bellard et al. 2013). Although sometimes used as a source of wood or other goods, alien tree species are highly dangerous for both native biodiversity and the economy (Vitousek et al. 1997; Chapin et al. 2000). Biological invasions are already one of the most significant problems for maintaining biodiversity today, but climate change will strongly enforce their negative effects on the future environment (Stachowicz et al. 2002; Walther et al. 2009). These are, e.g., reduced efficiency of wood production, loss of biodiversity, hybridization with native species, or cascading changes among habitats (Huxel 1999; Díaz and Cabido 2001). Therefore, it is obvious that this topic is of interest for a wide group of researchers and entrepreneurs (Mellert et al. 2015; Kariyawasam et al. 2019).

One of the tools that allows predictions of species future ecological optima is ecological niche modeling (Pearson and Dawson 2003). Still, often unpredictable processes of biological invasions and difficult to quantify mechanisms of warming climate make projecting future invasions a truly interdisciplinary challenge (Wiens et al. 2009). Confirmations of this difficulty are, e.g., different emission scenarios and global circulation models (GCMs) available and widely used in species modeling (Pearson et al. 2006; Goberville et al. 2015). Moreover, as the biogeographical origin of some species is not always clearly determined, it is worth noting that determining biogeographical origin is highly significant in the following stages of preparing a projection. It is particularly problematic in a case where naturalized species, already occurring in certain areas for ages, starts to show a strongly expansive character (Kowarik 1995). Moreover, sometimes it is unknown whether a biogeographic barrier, dividing primary and introduced ranges, could be spontaneously broken due to change of climatic conditions constituting the barrier. English walnut (Juglans regia L.) is an example of a species being widely distributed in Europe and exhibiting high invasiveness in its secondary range (Lenda et al. 2018).
Despite its importance for food and wood production, up to now there have been no studies predicting changes of J. regia distribution in future climate conditions. The exception was a study of Ranjitkar et al. (2016) testing possibilities of J. regia introduction into agroforestry plantations in China. Therefore, we aimed to (1) predict the future climatic optimum of J. regia in Europe based on climatic data, (2) assess the most important climatic factors that determine the potential distribution of the species studied, and (3) compare the results obtained among three different GCMs used.

\section{Methods}

\section{Studied species}

The English walnut (Juglans regia L., Juglandaceae) is a long-lived, deciduous tree with silver-gray bark, reaching a height of approximately $30 \mathrm{~m}$ (de Rigo et al. 2016). The tree, of up to $2 \mathrm{~m}$ diameter, produces high-quality timber which often achieves high prices, and can be used in agroforestry. The wood is appreciated in terms of esthetics and easy to process, often being used for luxury furniture or veneer. Abundant in unsaturated fatty acids, proteins, and vitamins, and characterized by a multiplicity of pro-health properties, the nuts have numerous uses not only in dietetics but also in medicine (Martínez et al. 2010; Carvalho et al. 2010).

The origin of English walnut in Europe is a contentious issue. The species probably originally derived from the Mediterranean and Central Asia. Palynological data suggests that $J$. regia occurred in western Europe and the Balkans already during the last glacial stage in glacial refugia (Carrión and Sanchez-Gomez 1992; Pollegioni et al. 2014). However, as the species has been widely cultivated up to 6000 years ago, the primary distribution of its range has not been precisely assessed (McGranahan and Leslie 2009). However, it was both an attractive, durable wood (Miller 1976) and has numerous possibilities for use of the nuts (Özcan 2009) that led to intense planting of $J$. regia from the Middle Ages across the continent. For the same reason, nowadays it is a tree species of high economic importance, particularly in the Black Sea region, with Turkey being the third largest walnut producer in the world (Ercisli et al. 2012). It can be found in almost all of Europe, except for the northernmost areas (de Rigo et al. 2016). The most favorable conditions for the species cover mean annual temperatures ranging from 10.5 up to $15{ }^{\circ} \mathrm{C}$, and annual precipitation exceeding $600 \mathrm{~mm}$ (Bernyi et al. 1991).

Although it has relatively high habitat requirements, nowadays $J$. regia is the most widely spread nut tree in the world (de Rigo et al. 2016). Through the passing ages, there were no symptoms of its invasion on the terrain of 
Europe; however, it was easily naturalized, propagated both by seeds and vegetatively (Kowarik 1995). The last decades showed the hidden invasiveness of the species by the alarming rate of appearance of new, juvenile specimens, even in harsh habitats (Loacker et al. 2007). This may be caused by the lag-phase, relatively long for such long-living organisms as trees (Wangen and Webster 2006). Today, multiple potential dangers of J. regia invasiveness are noticed in the context of nature conservation and environmental management. The main source of these threats is connected with English walnut's allelopathic properties (Aliskan and Terzi 2001), interfering with the existing trophic networks and the potential of fast dispersion through zoochory. For that reason, the analysis of the future range of this species in changing climate conditions is particularly important in the context of its possible use in economy and nature conservation.

\section{Data collection}

We collected data on the current $J$. regia distribution across Europe $\left(10^{\circ} \mathrm{W}\right.$ to $45^{\circ} \mathrm{E}$ and $33^{\circ} \mathrm{N}$ to $\left.72^{\circ} \mathrm{N}\right)$. This area was divided into grids of $2.5^{\prime}$ resolution, with a total of $1,235,520$ raster cells. We compiled a list of J. regia observations, based on the Global Biodiversity Information Facility (GBIF 2019; Fig. 1). We excluded observations from botanical gardens, arboretums, parks, or noted before 1950. The lack of species occurrence in eastern Europe in the model results from deficiency of presence data rather than from lack of plantation or climatic barriers inhibiting the spread of $J$. regia into the region of the Baltic countries, Belarus or Ukraine. Due to geographical sampling bias, connected with uneven distribution of sampling (Rocchini and Garzón-López 2017), we completed it with literature data from Poland, increasing the amount of data from the area of transitional climate (Lenda et al. 2018).

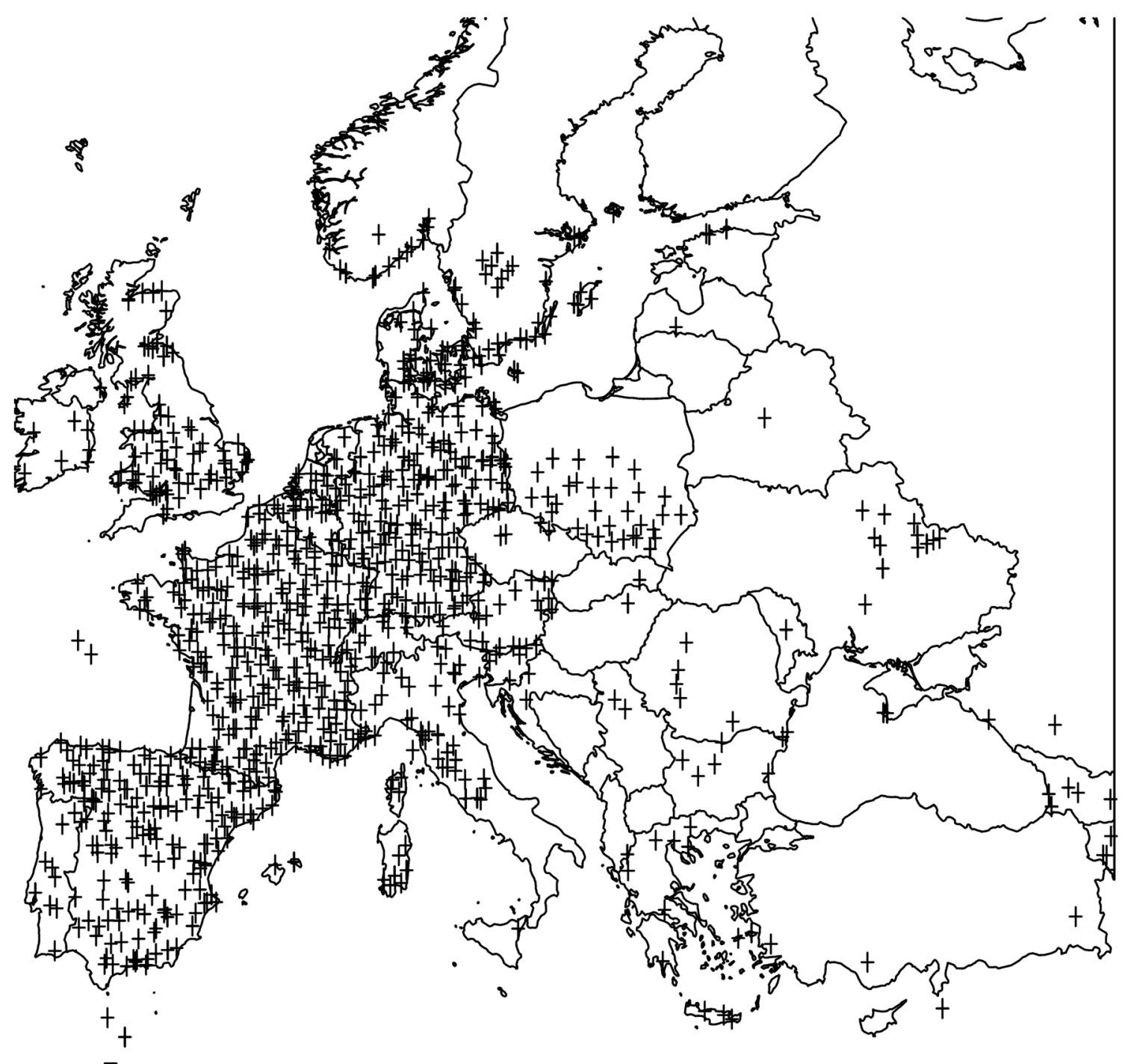

Fig. 1 Current distribution data of Juglans regia obtained from the Global Biodiversity Information Facility database (GBIF 2019) and Lenda et al. (2018) after resampling $(n=998)$ 
Although it could influence our results, we believe that the relatively well-mapped distribution in Western Europe helps in revealing climatic-dependent trends in species occurrence. The problem of low and uneven data coverage is frequent in species distribution data (Cornwell et al. 2019). We decided not to include geographical range information providing the shape of extent of areas occupied by J. regia (de Rigo et al. 2016), as this species is scattered. Thus, a large proportion of such an area represents potential, not actual, distribution of J. regia. In total, we obtained 38,554 presence points. To avoid uneven sampling bias and pseudoreplications, we resampled observations using a larger grid (30' resolution): we randomly selected only one data point within each $30^{\prime}$ grid square to obtain uniform density of distribution points, following Dyderski et al. (2018). This procedure prevented having a prevailing number of observations from a particular, wellstudied region, which could influence the results by multiplying the weight of particular observations. After resampling, we obtained 998 data points, which is sufficient for MaxEnt modeling (Phillips et al. 2006), as for this approach minimal sample size for effective estimation varies between 14 and 25 observations (van Proosdij et al. 2016).

For modeling, we used 19 variables describing variation in temperature and precipitation, further called bioclimatic variables (Table 1), derived from monthly temperature and precipitation records (Hijmans et al. 2005; O'Donnell and Ignizio 2012). This set of variables is used in species distribution modeling since the late 1980s (Booth et al. 2014; Booth 2017, 2018). We did not include other variables describing habitat (e.g., land use, soil type), as at the continental scale the climate is the main factor shaping species distributions (Pearson and Dawson 2003). For climate change projections for 2061-2080, we used projected values of 19 bioclimatic variables obtained from three emission scenarios and from three global circulation models (GCMs). Three emission scenarios are optimistic, moderate, and pessimistic, expressed by the representative concentration pathways (RCPs) - difference of radiative forcing between the 1986-2005 period and 2100 (van Vuuren et al. 2011; Harris et al. 2014). The optimistic scenario- $\mathrm{RCP} 2.6$ - assumes that in $2100 \mathrm{CO}_{2}$ concentration will reach $450 \mathrm{ppm}$, and global mean temperatures will increase to $0.2-1.8^{\circ} \mathrm{C}$ and has no strict reference in previous (AR4) IPCC guidelines. The moderate scenarioRCP4.5-assumes $650 \mathrm{ppm} \mathrm{CO}_{2}$ and $1.0-2.6{ }^{\circ} \mathrm{C}$ in 2100 and refers to AR4 guideline scenario $\mathrm{B} 1$. The pessimistic scenario- $\mathrm{RCP} 8.5$ - assumes $1350 \mathrm{ppm} \mathrm{CO}_{2}$ and $2.6-4.8^{\circ} \mathrm{C}$ in 2100 and refers to A1F1 scenario of IPCC AR4 guidelines (van Vuuren et al. 2011; Harris et al. 2014). As GCMs differ in projected responses, we used three of them which Goberville et al. (2015) found reflecting low, moderate ,and high changes in predicted distribution for two sample species. These GCMs were HadGEM2-ES (Jones et al. 2011), IPSLCM5A-LR (Dufresne et al. 2013), and MPI-SM-LR (Giorgetta et al. 2013). We downloaded raster maps of current
Table 1 Overview of bioclimatic variables used in this study and their importance in the species distribution model

\begin{tabular}{|c|c|c|}
\hline Abbreviation & Parameter & $\begin{array}{l}\text { Variable importance } \\
{[\%]}\end{array}$ \\
\hline BIO1 & Annual mean temperature $\left[{ }^{\circ} \mathrm{C}\right]$ & 4.04 \\
\hline $\mathrm{BIO} 2$ & Mean diurnal range (mean of monthly (max temp-min temp)) $\left[{ }^{\circ} \mathrm{C}\right]$ & 0.84 \\
\hline $\mathrm{BIO} 3$ & Isothermality $(\mathrm{BIO} 2 / \mathrm{BIO} 7)(* 100)\left[{ }^{\circ} \mathrm{C}\right]$ & 0.10 \\
\hline $\mathrm{BIO} 4$ & Temperature seasonality (standard deviation $* 100$ ) $\left[{ }^{\circ} \mathrm{C}\right]$ & 38.07 \\
\hline BIO5 & Max temperature of warmest month $\left[{ }^{\circ} \mathrm{C}\right]$ & 2.59 \\
\hline BIO6 & Min temperature of coldest month $\left[{ }^{\circ} \mathrm{C}\right]$ & 2.35 \\
\hline BIO7 & Temperature annual range $(\mathrm{BIO} 5-\mathrm{BIO} 6)\left[{ }^{\circ} \mathrm{C}\right]$ & 24.51 \\
\hline $\mathrm{BIO} 8$ & Mean temperature of wettest quarter $\left[{ }^{\circ} \mathrm{C}\right]$ & 0.08 \\
\hline BIO9 & Mean temperature of driest quarter $\left[{ }^{\circ} \mathrm{C}\right]$ & 0.86 \\
\hline $\mathrm{BIO} 10$ & Mean temperature of warmest quarter $\left[{ }^{\circ} \mathrm{C}\right]$ & 0.31 \\
\hline BIO11 & Mean temperature of coldest quarter $\left[{ }^{\circ} \mathrm{C}\right]$ & 9.88 \\
\hline $\mathrm{BIO} 12$ & Annual precipitation $[\mathrm{mm}]$ & 2.46 \\
\hline $\mathrm{BIO} 13$ & Precipitation of wettest month $[\mathrm{mm}]$ & 0.34 \\
\hline $\mathrm{BIO} 14$ & Precipitation of driest month [mm] & 0.17 \\
\hline $\mathrm{BIO} 15$ & $\begin{array}{l}\text { Precipitation seasonality (coefficient of variation: mean/SD * 100) } \\
{[\%]}\end{array}$ & 5.69 \\
\hline $\mathrm{BIO} 16$ & Precipitation of wettest quarter $[\mathrm{mm}]$ & 0.00 \\
\hline $\mathrm{BIO} 17$ & Precipitation of driest quarter $[\mathrm{mm}]$ & 3.69 \\
\hline $\mathrm{BIO} 18$ & Precipitation of warmest quarter $[\mathrm{mm}]$ & 0.59 \\
\hline BIO19 & Precipitation of coldest quarter [mm] & 3.42 \\
\hline
\end{tabular}


(1950-2000) and projected (2061-2080) bioclimatic variables at $2.5^{\prime}$ resolution from the WorldClim 1.4 dataset (http://www. worldclim.org/; Hijmans et al. 2005). For summary statistics of these datasets, see supplementary materials in Dyderski et al. (2018).

\section{Data analysis}

We performed the process of modeling following the methodology described by Dyderski et al. (2018). We used MaxEnt modeling, as this procedure is widely used in species distribution modeling and it is robust to real absence data, which can influence model outcome settings (Phillips et al. 2006, 2017; Elith et al. 2011). MaxEnt tests the patterns of occurrence (presence points) against randomly selected pseudoabsence points. Model input is a layer with presence data (points) and climatic variables (rasters), while model output is a raster layer with predicted occurrence probabilities. This output can be interpreted as the climatic optimum of the species studied-a climatic niche sensu (Hutchinson 1957). For modeling, we used the MaxEnt model with default settings (Phillips et al. 2006, 2017; Elith et al. 2011), implemented in the dismo package (Hijmans et al. 2017) in R software (R Core Team 2019). We chose this approach as we obtained presence-only data; thus, we cannot make conclusions about absences. MaxEnt does not use absence data but instead it generates background data (i.e., pseudoabsences) — randomly selected points (in our study 10,000 points) within the study area. As MaxEnt is oriented to detecting patterns of presence points distinct from the background, we decided to use prevalence of background points to make the model more conservative than in the case of equal numbers of presence and absence points (Elith et al. 2011). For modeling, we used $80 \%$ of the data points (i.e., 800 data points), and the remaining $20 \%$ (198) were used for independent testing by area under receiver operator curve (AUC). This measure reflects model performance according to its sensitivity and specificity. For discrimination of MaxEnt results (probability) into presence/absence, we calculated the threshold value of probability at which the sum of the sensitivity and specificity was highest, to balance false positives and false negatives (Fielding and Bell 1997), assuming that the model output is a geographic range projected for each species representing the climatic optimum, i.e., climatic niche (Hutchinson 1957). We assessed the importance of variables using a heuristic estimate based on an increase of regularized gain in each iteration of model run, implemented in the MaxEnt algorithm (Phillips et al. 2006, 2017; Elith et al. 2011). To assess J. regia response to particular bioclimatic variables, we provided partial dependence plots, showing model response to single predictors. For the assessment of the threat level, we used the resampled dataset $(n=998)$ as a spatially stratified sample. We extracted values of $J$. regia occurrence probability for these points for each climate change scenario and GCM and calculated proportion of points remaining within the climatically suitable area.

\section{Results}

\section{Current distribution model}

The current distribution model AUC reached 0.871, which indicates good fitness of the model (Swets 1988). Among bioclimatic variables, the most important predictors were temperature seasonality $(38.07 \%)$ and temperature annual range (24.51\%; Table 1). Mean temperature of the coldest quarter had an importance of $9.88 \%$ and precipitation seasonality of $5.69 \%$. The rest of the bioclimatic variables had the importance lower than $5 \%$. Probability of J. regia occurrence decreased with increasing temperature seasonality and mean coldest quarter seasonality (although its effect size was negligible), while it increased with increasing temperature annual range and precipitation seasonality (Fig. 2). Patterns of other predictors were driven mainly by single observations. The predicted current, climatic optimum range of J. regia covers an extensive area in Europe, finding its climatic optimum in western Europe, particularly in France, Germany, and the southern part of Great Britain (Fig. 3). Moreover, southern Europe, i.e., Spain, Italy, and the Balkans, as well as Poland and southern Sweden, also lay within the threshold of the species occurrence.

\section{Projections of future J. regia distribution}

The projections of $J$. regia climatic-based range for the period 2061-2080 revealed that the species can strongly shift its range of occurrence northward (Fig. 4). The northward shift of the potential distribution proceeds with increasing mean annual temperatures assigned to specific climatic scenarios. The least severe changes are projected by application of the RCP2.6 scenario. It is quite similar to the current species range and indicates moderate northward shift, for example, proving that southern Scandinavia will meet the criteria of climatic optimum for the species. That scenario is generally suitable for J. regia to still occur in Italy, northern Spain, the Balkans, and coasts of the Black Sea.

In the case of the RCP4.5, the potential distribution of $J$. regia shifts northwest, projecting occurrence of the species, for example, in Scotland, Denmark, and southern Sweden. At the same time, there are losses of suitable area in the south, i.e., in Spain, Italy, southern France, or the Balkans. Although there are still numerous localities suitable for the species in France, Germany, and England, it is visible that the potential range is greatly less homogeneous.

As the harshest scenario, RCP8.5 indicates the sharpest changes in the climatic optimum. Only a few, strongly 

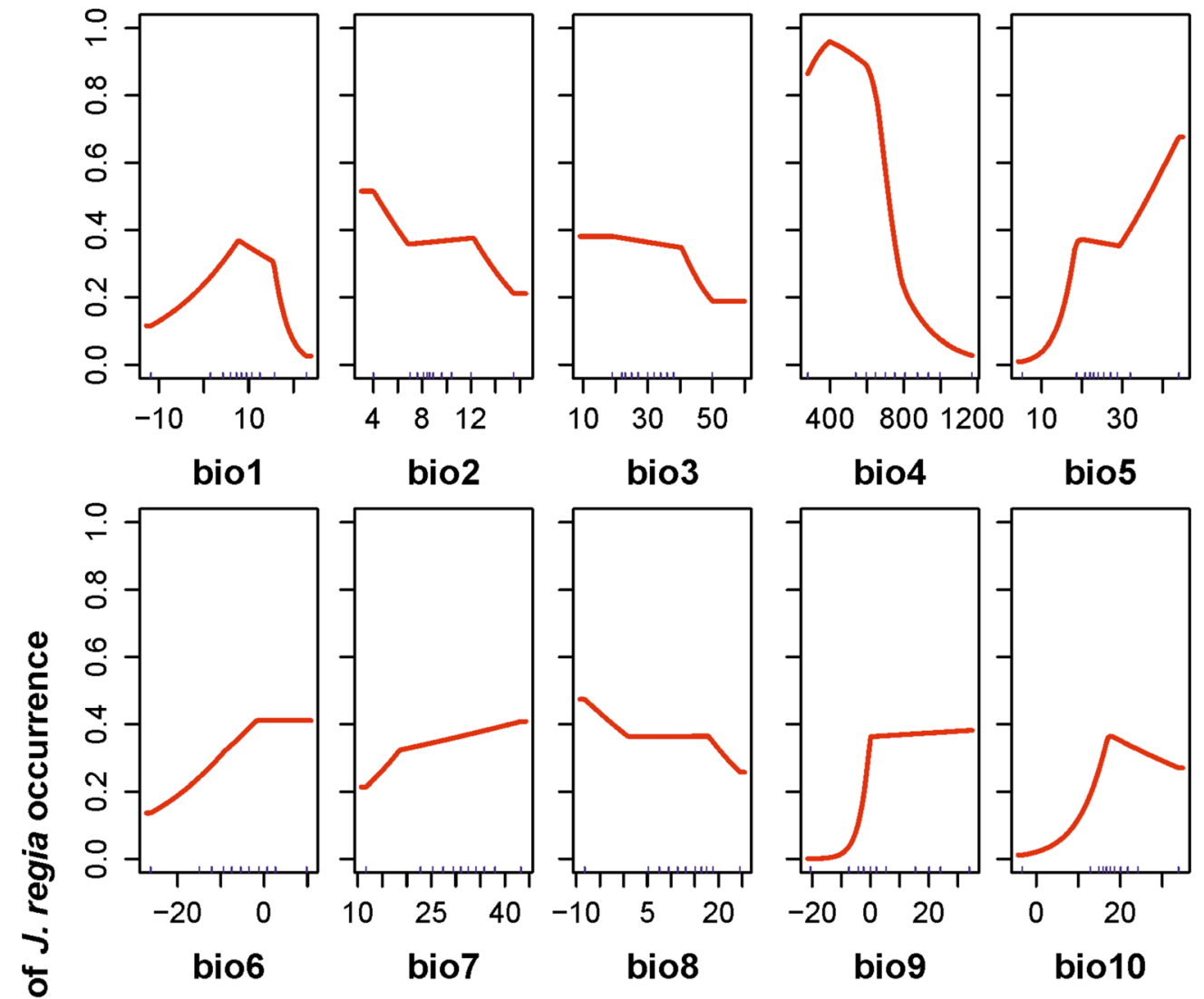

bio2

bio3
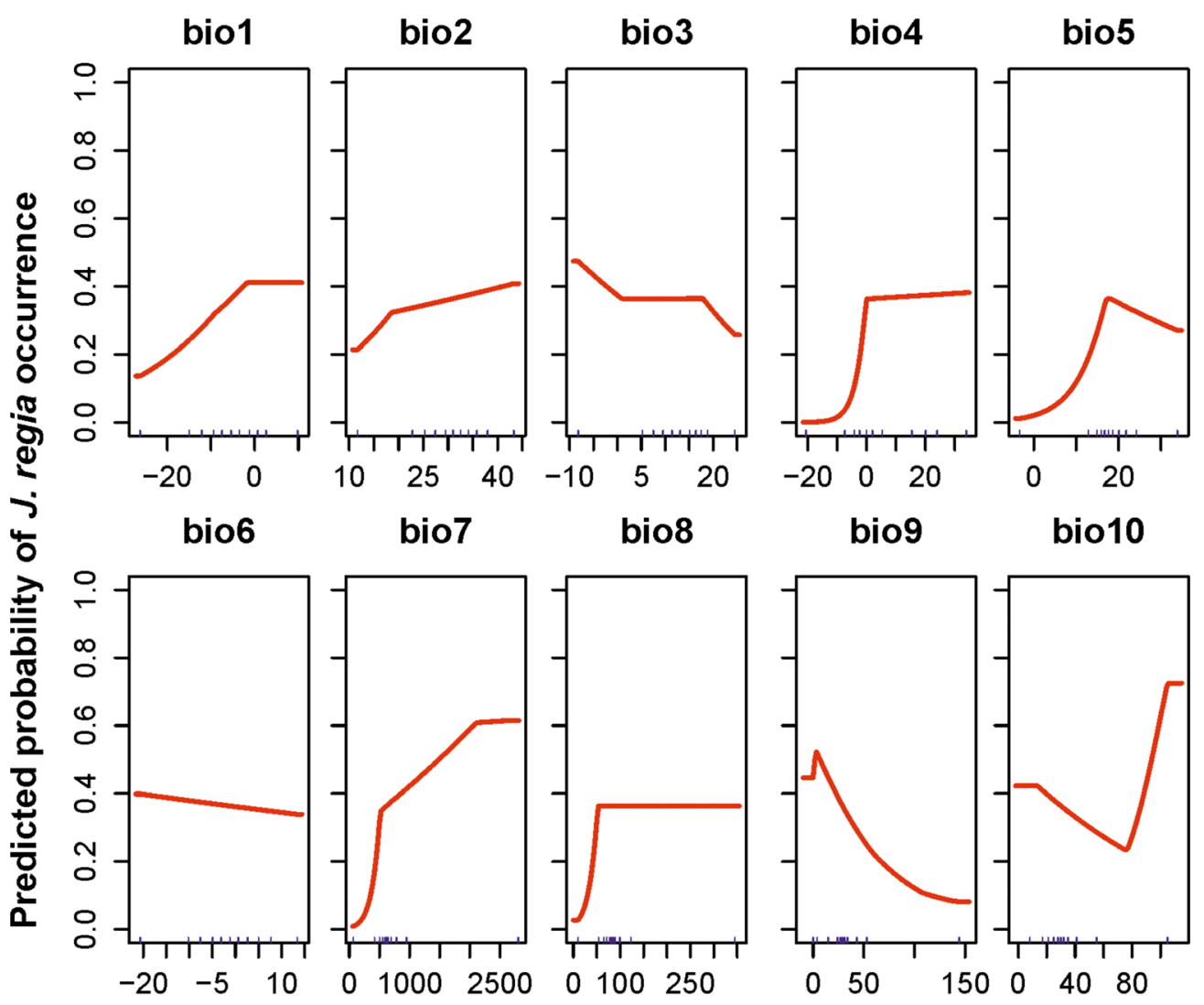

bio11

bio12

bio13
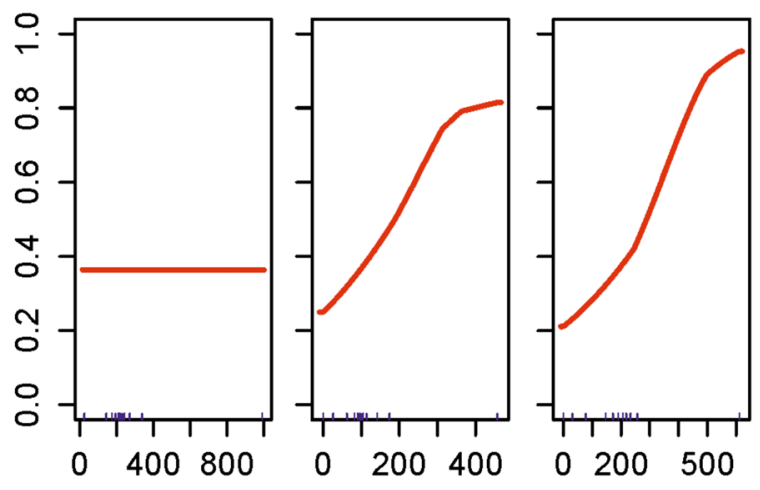

bio14

bio15

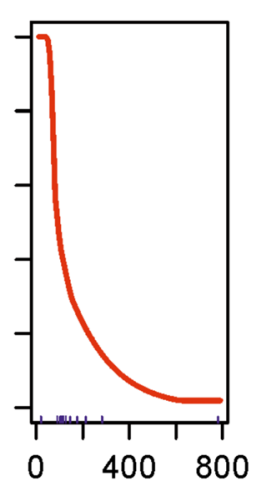

\section{bio16}

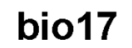

bio18

bio19

Fig. 2 Partial prediction of Juglans regia occurrence probability along each of the bioclimatic variables (see Table 1 for abbreviations). Red line: predicted response to a particular bioclimatic variable; small rugs at the bottom of each panel reflect the distribution of a particular independent variable 
fragmented suitable areas will remain in Italy, the Balkans, Spain, and the Black Sea region. France, Germany, and Poland will also lose a significant part of the currently suitable places for J. regia growth.

While the main trends of changes were the same in all combinations of scenarios and GCMs, we found differences in the results among GCMs used in model preparation (Fig. 4). The least severe GCM was the MPI-SM-LR model, which showed only slight differences among scenarios, and even in the case of RCP8.5, a majority of the current range was still in the climatic optimum. The most severe model was HadGEM2-ES. In the case of RCP8.5, this model showed that less than $15 \%$ of the current range will remain in Europe, including great losses in France, Germany, Poland, Italy, and the Balkans. IPSL-CM5A-LR was a moderate model, transitional between MPI-SM-LR and HadGEM2-ES, indicating gradual changes among different climatic scenarios.

It is worth noting that in 50 years the area of the UK, Denmark, and Pyrenees will be suitable for J. regia regardless of the scenario or GCM applied, even though the more severe the scenario, the less current distribution remains in the climatic optimum zone.

\section{Differences of range extent among global circulation models}

The percentage share of the current distribution remaining in the climatic optimum varied among different GCMs (Fig. 5). The general trend of the differences was independent from the

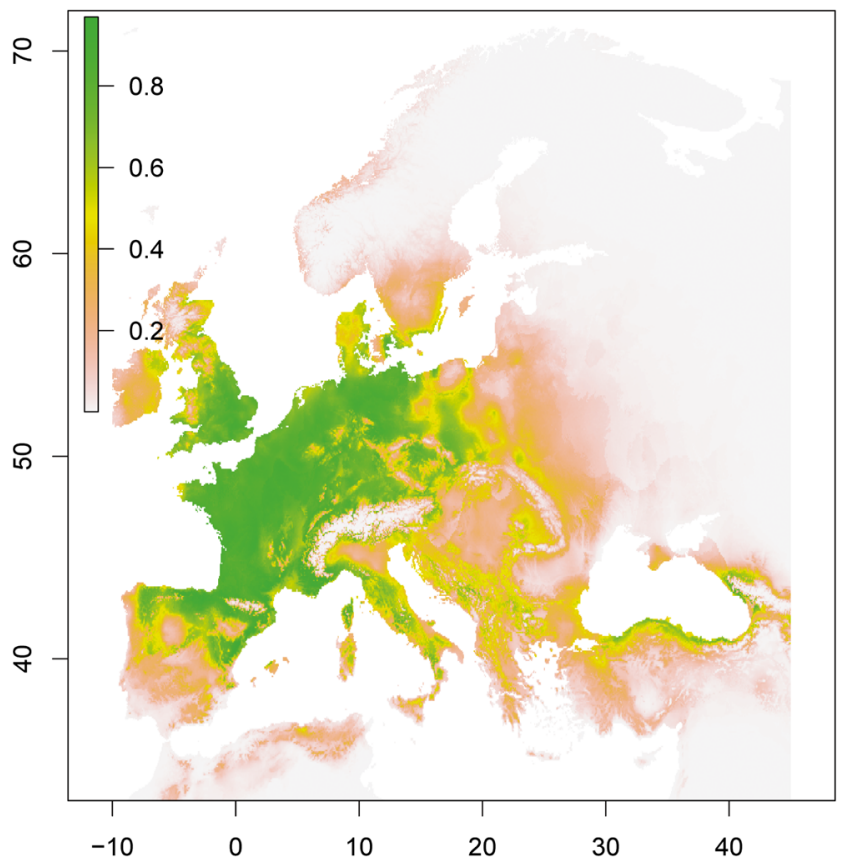

Fig. 3 Predicted habitat suitability for Juglans regia using the current (1960-1990) climatic data. According to the maximum specificity and sensitivity, pixels with habitat suitability $>0.4348$ are claimed to be within the predicted range climatic scenario applied: the higher the temperatures predicted, the less suitable areas for J. regia. However, the differences in percentage share of the current distribution of $J$. regia remaining in climatic optimum among GCMs deepened with increasing severity of the climatic scenario. For example, for the RCP2.6 scenarios, the differences among adjoining GCMs did not exceed $10 \%$ of the current distribution, and for the RCP 8.5 scenarios, the differences were higher than $20 \%$. Comparing GCMs that differed the most, the differences for RCP2.6 did not exceed 15\%, while for RCP8.5, the differences were higher than $40 \%$ within a particular climatic scenario.

\section{Discussion}

\section{Comparison of $J$. regia distribution shift projections with other species}

According to our findings, future climatic optimum of J. regia, regardless of the climatic scenario or GCM applied, can shift northward in a significant way. Thus, current range of the species, particularly on the southern border, can face contraction of its climatic optimum within 50 years. This can result in loss of valuable genetic resources of populations (Schueler et al. 2014; Büntgen et al. 2019) located in southern Europe, where the species remains one of the most economically important tree species (Ercisli et al. 2012; de Rigo et al. 2016). While considering future species distributions, a comparison between ecological requirements of species can be useful in the context of forest management or nature conservation (Dyderski et al. 2018; Thurm et al. 2018).

Our study showed that the main driver of distribution shift will be increase of climate seasonality, connected with both annual temperature range and temperature and precipitation seasonality. These variables were also important for three central European cold-sensitive tree species: Abies alba, Fagus sylvatica, and Quercus petraea (Dyderski et al. 2018). Increased climatic seasonality seems to be more important as a limiting factor at the northern border of the current distribution, as this species is sensitive to frost (Loacker et al. 2007). For that reason, low seasonality of precipitation and temperature will be the most responsible for predicted $J$. regia refugia in oceanic and montane climates.

In our study, we predicted a northward shift of J. regia, similar to the majority of studies on European tree species (e.g., Metzger et al. 2008; Boisvert-Marsh et al. 2014; Dyderski et al. 2018). However, that shift differs among species of different ecological strategies. In recent studies including analyses of the forest-forming species, the species showing similar trends as $J$. regia were, e.g., $Q$. petraea, $Q$. robur, or $F$. sylvatica (Dyderski et al. 2018). It can be easily seen that those species have numerous common features with $J$. regia (e.g., deciduousness, high seed mass, low frost resistance). 
RCP2.6
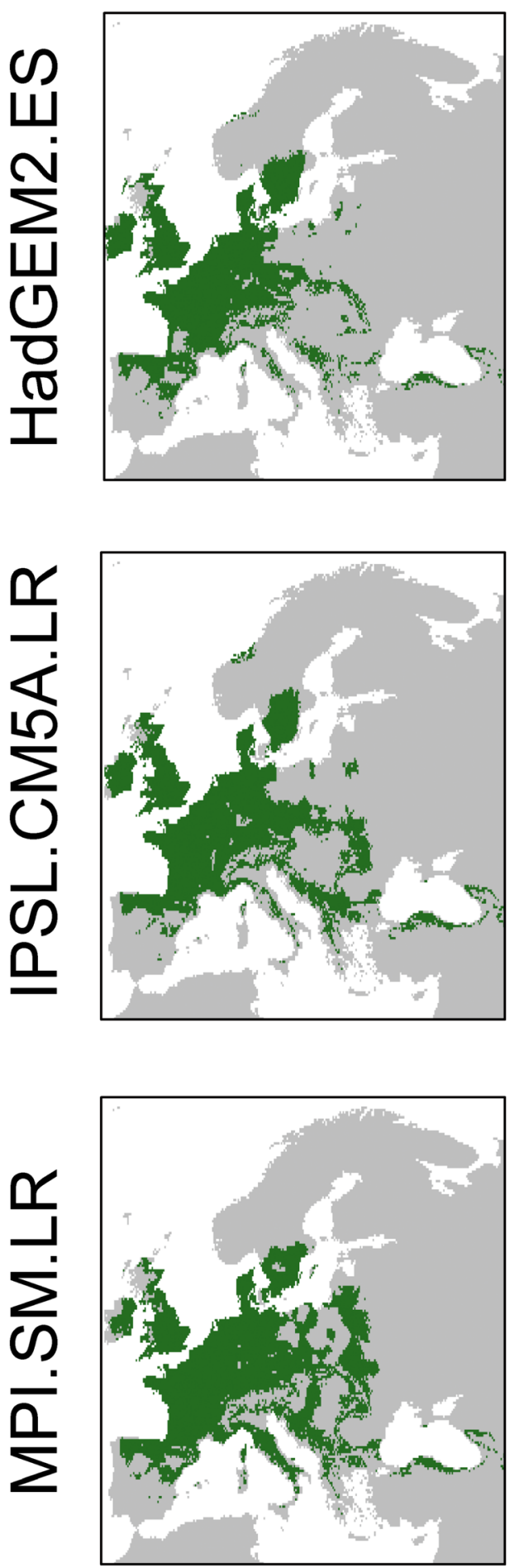

Fig. 4 Predicted habitat suitability for $J$. regia using projected (20612080) climate conditions for optimistic (RCP2.6), moderate (RCP4.5), and pessimistic (RCP8.5) scenarios and three climate models. Green

This should lead to modification of plans for species composition of tree stands, as there is a need for alternative species usable in forestry (Thurm et al. 2018). As tree species today regarded as irreplaceable in Europe (as, e.g., Pinus sylvestris,
RCP4.5
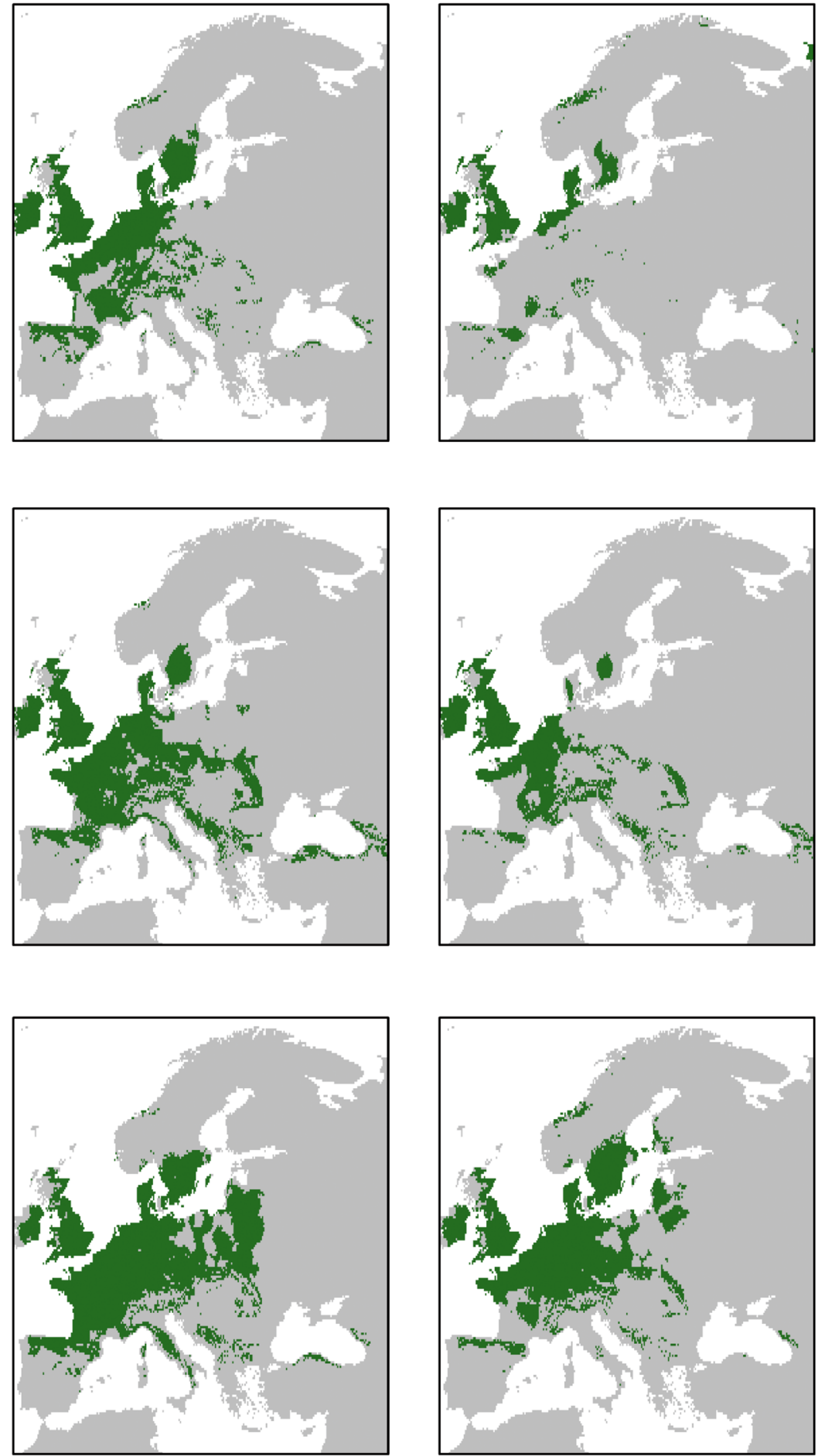

area represents pixels with habitat suitability $>0.4348$, claimed to be within predicted range

Picea abies) may suffer an unprecedented decline within several decades (Hanewinkel et al. 2013; Dyderski et al. 2018; Thurm et al. 2018), this is an issue of great economic importance, thus implying that species of late-successional stages, 
Fig. 5 Fraction of distribution sample ( $n=998$, spatially stratified sample) which remain in climatically suitable area in 20612080 under different climate change scenarios and GCMs

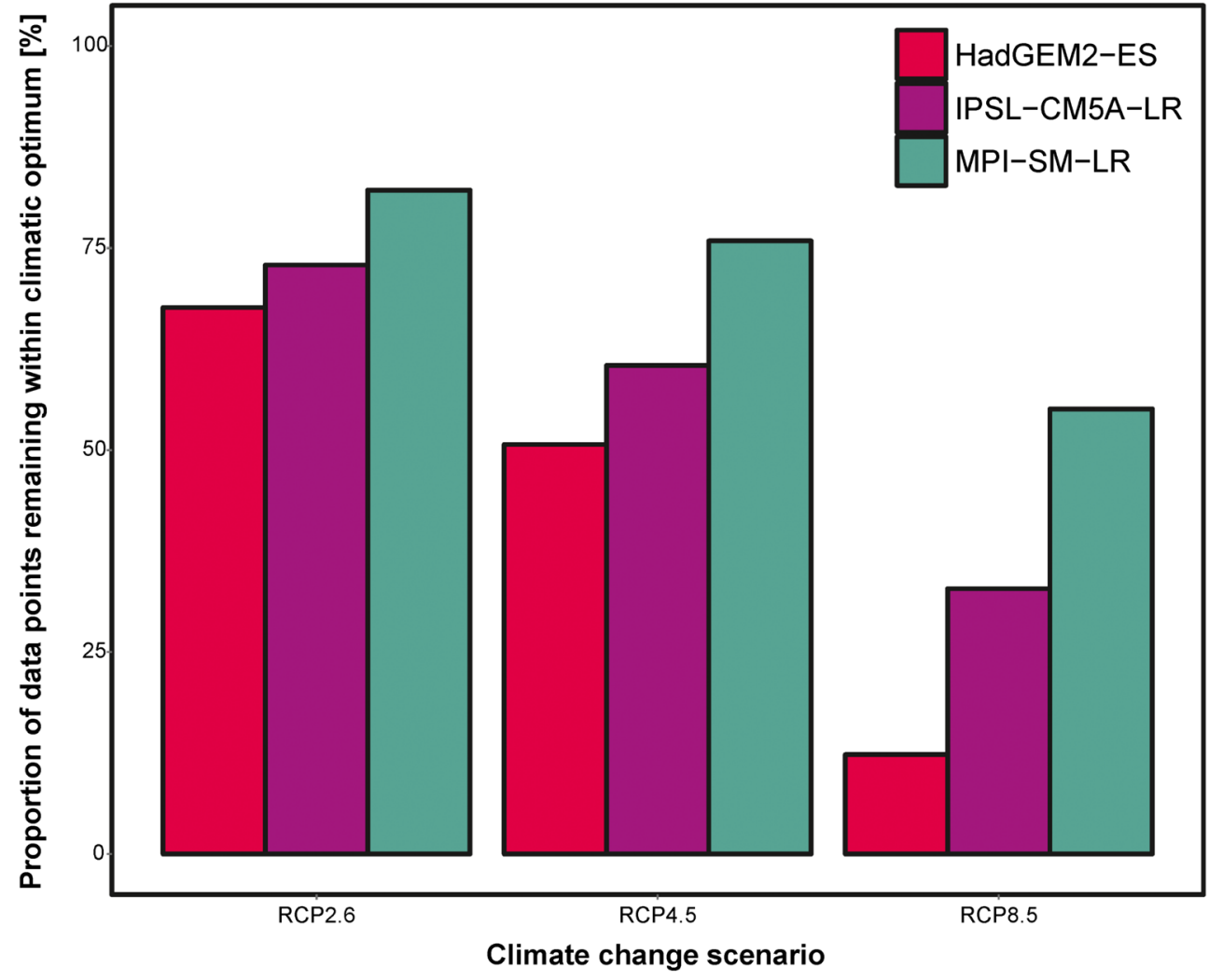

collected and available, and data on the non-colonized area is not available at all (Warton et al. 2013). However, as has already been suggested, the drawbacks of such methods are not a reason to disregard them (Oliver et al. 2016).

The next obvious source of uncertainty are the RCPs (van Vuuren et al. 2011). There is high variability among the climatic scenarios, resulting among other factors, from lack of reliable estimates of emissions levels in future decades (Riahi et al. 2011). With the dynamic development of niche modeling in modern ecology, the concept of including numerous RCPs should become common (Thuiller et al. 2019). However, previous research often limited the methodology to only a single RCP (Remya et al. 2015; Camenen et al. 2016). This can lead to studies of implementational specifics which do not take the uncertainty of varied scenarios into account, which can greatly influence the results (Matsui et al. 2009). A subjective choice of a single climatic scenario can lead to serious consequences at the level of nature conservation or ecosystem management. As the conclusions of numerous studies on possible species ranges are often synthesized while provided to decision-makers, entrepreneurs, and conservationists (Beale and Lennon 2012), it is fundamental not to blur the wide range of uncertainty while adapting the methodology to the aim of the research.

The GCMs used are another often underestimated source of uncertainty (Goberville et al. 2015). Meanwhile, the GCM used is one of the most significant factors that impacts the differentiation among projections (Thuiller et al. 2019). As the current distributions of most tree species is only partially 
we proved, the GCM used can significantly influence the results of a projection, although the greatest differences among scenarios were caused by varying the RCP. According to Thuiller (2019), while considering projections which do not take into account the dispersion rate, GCMs are the second most important factor influencing the results obtained, after RCPs. What is more, Goberville et al. (2015) found that the variability arising from GCM was even greater for the next decades compared to variability caused by the RCP used, although the levels of these uncertainties achieved similar values by 2100 . It is worth noticing that, the more severe the scenario, the greater the dispersion among the GCMs applied (Fig. 4). Taking into consideration the possibility of climatic changes similar to those projected by RCP8.5 (Riahi et al. 2011), the variability of possible model outcomes results in lack of credibility of the implementation tips provided. To avoid misunderstandings, it is necessary to test multiple GCMs, as well as RCPs, or elements causing uncertainty at other levels of modeling, such as species distribution models (Goberville et al. 2015; Thuiller et al. 2019).

\section{Consequences of model uncertainty}

Considering the wide range of uncertainty sources (Pearson and Dawson 2003; Thuiller et al. 2019), a thorough understanding of uncertainty consequences is even more important in the context of climate change. One of the biggest challenges of today's conservation is the maintenance of genetic diversity of species (Rajora and Mosseler 2001). The preservation of the wide range of genetic diversity among populations can be implemented only when potential range of distribution is assessed properly. This can be a significant problem in the case of such long-living organisms as trees, which are unable to create sustainable populations under conditions of progressive changes (Kuparinen et al. 2010). The concept of assisted migration is a proposed solution to prevent extinction of certain parts of genetic resources (McLachlan et al. 2007; Gray et al. 2011). It is a climate change adaptation strategy consisting of large-scale transfer of locally adapted populations into a more suitable climate. However, a number of conditions must be met for such an initiative to be successful. Even if such a project would meet its expectations, progressive climate change will make it difficult to maintain the resources protected. Thus, the most problematic question of this alternative is where to plant the populations transferred, as they may be in the risk zone anyway.

On the other hand, extinction of species is not the only danger connected with biodiversity loss of unprecedented scale (Díaz and Cabido 2001). The spread of alien invasive species displacing native species (Chapin et al. 2000), sometimes even with the ability to transform the habitat occupied (Richardson et al. 2000; Taylor et al. 2017), is also a driver of environmental changes. Although it may vary among different schemes (Křivánek and Pyšek 2006), risk assessment is crucial in the context of managing both potentially threatening and threatened populations (Rouget et al. 2002). Taking numerous complex mechanisms determining the success of the invasion into consideration (Ren and Zhang 2009), it is obvious that providing a model of future distribution of a potentially invasive species is a difficult task. It should be highlighted that, when combining the uncertainty of future species management strategies to all the possible sources of uncertainty during the modeling process, the level of uncertainty increases.

\section{Conclusions}

Climate change will strongly influence species distributions in the forthcoming decades (Pearson and Dawson 2003). Hence, it is a key issue not only to project future species ranges but also to modify and adapt plans of forest management and environmental protection to the potential changes (Spittlehouse and Stewart 2003). The predicted future climatic optimum of J. regia in Europe will shift northward, indicating the need for revising our expectations of future productivity of English walnut (Winter et al. 2009) plantations in southern Europe. Also, it will be crucial to reconsider the status of J. regia in Europe, as results indicate it may be threatened in the southern part of the continent, and potentially invasive in the northern areas. This highlights emerging challenges for conservationists, who should focus, among other issues, on the protection of genetic resources of historic populations of $J$. regia. The most significant bioclimatic variables that determine the potential species range were three factors connected with climate seasonality, indicating a shift from oceanic to continental climate. Therefore, attention should be paid to those factors as they will probably shape future range of the species. Although the general trends are common for the projections presented, the variability of our projections among the GCMs or climatic scenarios applied shows that a high dose of caution should be maintained when making decisions about management of populations.

Acknowledgments MKD acknowledges a doctoral scholarship from the National Science Centre, Poland, under the project no. 2018/28/T/NZ8/ 00290. We are grateful to Dr. Lee E. Frelich (Department of Forest Resources, University of Minnesota, USA) for linguistic revision of the manuscript. We are also thankful to the two anonymous reviewers for valuable comments on the earlier draft of the manuscript.

Funding The study was partially financed by the Institute of Dendrology, Polish Academy of Sciences.

Open Access This article is licensed under a Creative Commons Attribution 4.0 International License, which permits use, sharing, adaptation, distribution and reproduction in any medium or format, as long as you give appropriate credit to the original author(s) and the source, provide a link to the Creative Commons licence, and indicate if changes were made. The images or other third party material in this article are included in the article's Creative Commons licence, unless indicated otherwise in a credit line to the material. If material is not included in the article's 
Creative Commons licence and your intended use is not permitted by statutory regulation or exceeds the permitted use, you will need to obtain permission directly from the copyright holder. To view a copy of this licence, visit http://creativecommons.org/licenses/by/4.0/.

\section{References}

Aliskan IK, Terzi I (2001) Allelopathic effects of walnut leaf extracts and juglone on seed germination and seedling growth. J Hortic Sci Biotechnol 76:436-440. https://doi.org/10.1080/14620316.2001. 11511390

Beale CM, Lennon JJ (2012) Incorporating uncertainty in predictive species distribution modelling. Philos Trans R Soc B Biol Sci 367:247258. https://doi.org/10.1098/rstb.2011.0178

Bellard C, Thuiller W, Leroy B, Genovesi P, Bakkenes M et al (2013) Will climate change promote future invasions? Glob Change Biol 19:3740-3748. https://doi.org/10.1111/gcb.12344

Bernyi G, Csurka E, Srvri J, Szodtridt I (1991) Erfahrungen über den forstlichen Walnussanbau in Ungarn. Allgemeine Forstzeitschrift 12: 619-621

Boisvert-Marsh L, Périé C, de Blois S (2014) Shifting with climate? Evidence for recent changes in tree species distribution at high latitudes. Ecosphere 5:1-33. https://doi.org/10.1890/ES14-00111.1

Bolte A, Ammer C, Löf M, Madsen P, Nabuurs G-J et al (2009) Adaptive forest management in central Europe: climate change impacts, strategies and integrative concept. Scand J For Res 24:473-482. https:// doi.org/10.1080/02827580903418224

Booth TH (2017) Assessing species climatic requirements beyond the realized niche: some lessons mainly from tree species distribution modelling. Climatic Change 145:259-271. https://doi.org/10.1007/ s10584-017-2107-9

Booth TH (2018) Why understanding the pioneering and continuing contributions of BIOCLIM to species distribution modelling is important. Austr Ecol 43:852-860. https://doi.org/10.1111/aec.12628

Booth TH, Nix HA, Busby JR, Hutchinson MF (2014) Bioclim: the first species distribution modelling package, its early applications and relevance to most current MaxEnt studies. Divers Distrib 20:1-9. https://doi.org/10.1111/ddi.12144

Brundu G, Richardson DM (2016) Planted forests and invasive alien trees in Europe: a code for managing existing and future plantings to mitigate the risk of negative impacts from invasions. NeoBiota 30: 5-47. https://doi.org/10.3897/neobiota.30.7015

Büntgen U, Krusic PJ, Piermattei A, Coomes DA, Esper J et al (2019) Limited capacity of tree growth to mitigate the global greenhouse effect under predicted warming. Nat Commun 10:2171. https://doi. org/10.1038/s41467-019-10174-4

Camenen E, Porté AJ, Garzón MB (2016) American trees shift their niches when invading Western Europe: evaluating invasion risks in a changing climate. Ecol Evol 6:7263-7275. https://doi.org/10. 1002/ece 3.2376

Carrión JS, Sanchez-Gomez P (1992) Palynological data in support of the survival of walnut (Juglans regia L.) in the Western Mediterranean area during last glacial times. J Biogeogr 19:623-630. https://doi. org $/ 10.2307 / 2845705$

Carvalho M, Ferreira PJ, Mendes VS, Silva R, Pereira JA et al (2010) Human cancer cell antiproliferative and antioxidant activities of Juglans regia L. Food Chem Toxicol 48:441-447. https://doi.org/ 10.1016/j.fct.2009.10.043

Chapin FS, Zavaleta ES, Eviner VT, Naylor RL, Vitousek PM et al (2000) Consequences of changing biodiversity. Nature 405:234 242. https://doi.org/10.1038/35012241
Cornwell WK, Pearse WD, Dalrymple RL, Zanne AE (2019) What we (don't) know about global plant diversity. Ecography 42:1819 1831. https://doi.org/10.1111/ecog.04481

Czortek P, Delimat A, Dyderski MK, Zięba A, Jagodziński AM et al (2018) Climate change, tourism and historical grazing influence the distribution of Carex lachenalii Schkuhr - a rare arctic-alpine species in the Tatra Mts. Sci Total Environ 618:1628-1637. https:// doi.org/10.1016/j.scitotenv.2017.10.001

Davidson EA, Janssens IA (2006) Temperature sensitivity of soil carbon decomposition and feedbacks to climate change. Nature 440:165. https://doi.org/10.1038/nature04514

De Boeck HJ, Liberloo M, Gielen B, Nijs I, Ceulemans R (2008) The observer effect in plant science. New Phytol 177:579-583. https:// doi.org/10.1111/j.1469-8137.2007.02329.x

de Rigo D, Enescu CM, Houston Durrant T, Tinner W, Caudullo G (2016) Juglans regia in Europe: distribution, habitat, usage and threats. In: San-Miguel-Ayanz J, de Rigo D, Caudullo G, Houston Durrant T, Mauri A (Eds.) European atlas of forest tree species. Publ. Off. EU, Luxembourg, p e01977c+

Díaz S, Cabido M (2001) Vive la différence: plant functional diversity matters to ecosystem processes. Trends Ecol Evol 16:646-655. https://doi.org/10.1016/S0169-5347(01)02283-2

Dufresne J-L, Foujols M-A, Denvil S, Caubel A, Marti O et al (2013) Climate change projections using the IPSL-CM5 Earth System Model: from CMIP3 to CMIP5. Clim Dyn 40:2123-2165. https:// doi.org/10.1007/s00382-012-1636-1

Dyderski MK, Paź S, Frelich LE, Jagodziński AM (2018) How much does climate change threaten European forest tree species distributions? Glob Change Biol 24:1150-1163. https://doi.org/10.1111/gcb.13925

Dylewski Ł, Mikula P, Tryjanowski P, Morelli F, Yosef R (2017) Social media and scientific research are complementary-YouTube and shrikes as a case study. Sci Nat 104:48. https://doi.org/10.1007/ s00114-017-1470-8

Elith J, Phillips SJ, Hastie T, Dudík M, Chee YE et al (2011) A statistical explanation of MaxEnt for ecologists. Divers Distrib 17:43-57. https://doi.org/10.1111/j.1472-4642.2010.00725.x

Ercisli S, Sayinci B, Kara M, Yildiz C, Ozturk I (2012) Determination of size and shape features of walnut (Juglans regia L.) cultivars using image processing. Sci Hortic 133:47-55. https://doi.org/10.1016/j. scienta.2011.10.014

Fielding AH, Bell JF (1997) A review of methods for the assessment of prediction errors in conservation presence/absence models. Environ Conserv 24:38-49. https://doi.org/10.1017/S0376892997000088

GBIF (2019) GBIF Occurrence Download for Juglans regia L. Retrieved from Global Biodiversity Information Facility. https:// doi.org/10.15468/dl.4ksrxt

Giorgetta MA, Jungclaus J, Reick CH, Legutke S, Bader J et al (2013) Climate and carbon cycle changes from 1850 to 2100 in MPI-ESM simulations for the Coupled Model Intercomparison Project phase 5. J Adv Model Earth Syst 5:572-597. https://doi.org/10.1002/jame.20038

Goberville E, Beaugrand G, Hautekèete N-C, Piquot Y, Luczak C (2015) Uncertainties in the projection of species distributions related to general circulation models. Ecol Evol 5:1100-1116. https://doi. org/10.1002/ece 3.1411

Gray LK, Gylander T, Mbogga MS, Chen P-Y, Hamann A (2011) Assisted migration to address climate change: recommendations for aspen reforestation in western Canada. Ecol Appl Publ Ecol Soc Am 21:1591-1603. https://doi.org/10.2307/23023103

Hanewinkel M, Cullmann DA, Schelhaas M-J, Nabuurs G-J, Zimmermann NE (2013) Climate change may cause severe loss in the economic value of European forest land. Nat Clim Change 3: 203-207. https://doi.org/10.1038/nclimate1687

Harris RMB, Grose MR, Lee G, Bindoff NL, Porfirio LL et al (2014) Climate projections for ecologists. Wiley Interdiscip Rev Clim Change 5:621-637. https://doi.org/10.1002/wcc.291 
Hertin J, Berkhout F, Gann D, Barlow J (2003) Climate change and the UK house building sector: perceptions, impacts and adaptive capacity. Build Res Inf 31:278-290. https://doi.org/10.1080/ 0961321032000097683

Hickler T, Vohland K, Feehan J, Miller PA, Smith B et al (2012) Projecting the future distribution of European potential natural vegetation zones with a generalized, tree species-based dynamic vegetation model. Glob Ecol Biogeogr 21:50-63. https://doi.org/10. 1111/j.1466-8238.2010.00613.x

Hijmans RJ, Cameron SE, Parra JL, Jones PG, Jarvis A (2005) Very high resolution interpolated climate surfaces for global land areas. Int $\mathrm{J}$ Climatol 25:1965-1978. https://doi.org/10.1002/joc.1276

Hijmans RJ, Phillips S, Leathwick J, Elith JL (2017) dismo: Species Distribution Modeling. URL https:/CRAN.R-project.org/ package $=$ dismo. Accessed 15 Jan 2021

Hobbie SE, Chapin FS (1998) The response of tundra plant biomass, aboveground production, nitrogen, and $\mathrm{CO}_{2}$ flux to experimental warming. Ecology 79:1526-1544. https://doi.org/10.1890/00129658(1998)079[1526:TROTPB]2.0.CO;2

Hutchinson GE (1957) Concluding remarks. Cold Spring Harb Symp Quant Biol 22:415-427. https://doi.org/10.1101/SQB.1957.022.01.039

Huxel GR (1999) Rapid displacement of native species by invasive species: effects of hybridization. Biol Conserv 89:143-152. https://doi. org/10.1016/S0006-3207(98)00153-0

Jagiełło ZA, Dyderski MK, Dylewski Ł (2019) What can we learn about the behaviour of red and grey squirrels from YouTube? Ecol Inform 51:52-60. https://doi.org/10.1016/j.ecoinf.2019.02.006

Jones CD, Hughes JK, Bellouin N, Hardiman SC, Jones GS et al (2011) The HadGEM2-ES implementation of CMIP5 centennial simulations. Geosci Model Dev 4:543-570. https://doi.org/10.5194/gmd-4-5432011

Kariyawasam CS, Kumar L, Ratnayake SS (2019) Invasive plant species establishment and range dynamics in Sri Lanka under climate change. Entropy 21:571. https://doi.org/10.3390/e21060571

Kowarik I (1995) Time lags in biological invasions with regard to the success and failure of alien species. In: Pyšek P, Prach K, Rejmánek $\mathrm{M}$, Wade $\mathrm{M}$ (eds) Plant invasions: general aspects and special problems. SPB Academic Publishing, Amsterdam, pp 15-38

Kozlowski TT, Pallardy SG (1997) Growth control in woody plants. Academic Press, San Diego

Kremer A, Ronce O, Robledo-Arnuncio JJ, Guillaume F, Bohrer G et al (2012) Long-distance gene flow and adaptation of forest trees to rapid climate change. Ecol Lett 15:378-392. https://doi.org/10. 1111/j.1461-0248.2012.01746.x

Křivánek M, Pyšek P (2006) Predicting invasions by woody species in a temperate zone: a test of three risk assessment schemes in the Czech Republic (Central Europe). Divers Distrib 12:319-327. https://doi.org/10.1111/j.1366-9516.2006.00249.x

Kuparinen A, Savolainen O, Schurr FM (2010) Increased mortality can promote evolutionary adaptation of forest trees to climate change. For Ecol Manag 259:1003-1008. https://doi.org/10.1016/j.foreco.2009.12.006

Lenda M, Knops JH, Skórka P, Moroń D, Woyciechowski M (2018) Cascading effects of changes in land use on the invasion of the walnut Juglans regia in forest ecosystems. J Ecol 106:671-686. https://doi.org/10.1111/1365-2745.12827

Liberloo M, Calfapietra C, Lukac M, Godbold D, Luo Z-B et al (2006) Woody biomass production during the second rotation of a bioenergy Populus plantation increases in a future high $\mathrm{CO}_{2}$ world. Glob Change Biol 12:1094-1106. https://doi.org/10.1111/j.13652486.2006.01118.x

Lin Y-P, Deng D, Lin W-C, Lemmens R, Crossman ND et al (2015) Uncertainty analysis of crowd-sourced and professionally collected field data used in species distribution models of Taiwanese moths. Biol Conserv 181:102-110. https://doi.org/10.1016/j.biocon.2014.11.012

Lindner M, Fitzgerald JB, Zimmermann NE, Reyer C, Delzon S et al (2014) Climate change and European forests: what do we know, what are the uncertainties, and what are the implications for forest management? J Environ Manage 146:69-83. https://doi.org/10.1016/j.jenvman.2014. 07.030

Loacker K, Kofler W, Pagitz K, Oberhuber W (2007) Spread of walnut (Juglans regia L.) in an Alpine valley is correlated with climate warming. Flora - Morphol Distrib Funct Ecol Plants 202:70-78. https://doi.org/10.1016/j.flora.2006.03.003

Luo Y, McIntire EJB, Boisvenue C, Nikiema PP, Chen HYH (2019) Climatic change only stimulated growth for trees under weak competition in central boreal forests. J Ecol 108:36-41. https://doi.org/ $10.1111 / 1365-2745.13228$

Martínez ML, Labuckas DO, Lamarque AL, Maestri DM (2010) Walnut (Juglans regia L.): genetic resources, chemistry, by-products. J Sci Food Agric 90:1959-1967. https://doi.org/10.1002/jsfa.4059

Matsui T, Takahashi K, Tanaka N, Hijioka Y, Horikawa M et al (2009) Evaluation of habitat sustainability and vulnerability for beech (Fagus crenata) forests under 110 hypothetical climatic change scenarios in Japan. Appl Veg Sci 12:328-339. https://doi.org/10.1111/ j.1654-109X.2009.01027.x

McGranahan G, Leslie C (2009) Breeding walnuts (Juglans regia). In: Gradziel TM (ed) Breeding plantation tree crops: temperate species. Springer New York, New York, pp 249-273

McKenney DW, Pedlar JH, Lawrence K, Campbell K, Hutchinson MF (2007) Potential impacts of climate change on the distribution of North American trees. BioScience 57:939-948. https://doi.org/10. 1641/B571106

McLachlan JS, Hellmann JJ, Schwartz MW (2007) A framework for debate of assisted migration in an era of climate change. Conserv Biol 21: 297-302. https://doi.org/10.1111/j.1523-1739.2007.00676.x

McMichael AJ, Woodruff RE, Hales S (2006) Climate change and human health: present and future risks. Lancet 367:859-869. https:// doi.org/10.1016/S0140-6736(06)68079-3

Mellert KH, Deffner V, Küchenhoff H, Kölling C (2015) Modeling sensitivity to climate change and estimating the uncertainty of its impact: a probabilistic concept for risk assessment in forestry. Ecol Model 316: 211-216. https://doi.org/10.1016/j.ecolmodel.2015.08.014

Metzger MJ, Bunce RGH, Leemans R, Viner D (2008) Projected environmental shifts under climate change: European trends and regional impacts. Environ Conserv 35:64-75. https://doi.org/10.1017/ S0376892908004529

Miller RB (1976) Wood anatomy and identification of species of Juglans. Bot Gaz 137:368-377. https://doi.org/10.1086/336886

O'Donnell MS, Ignizio DA (2012) Bioclimatic predictors for supporting ecological applications in the conterminous United States. Geol Surv Data Ser 691:1-10

Oliver TH, Smithers RJ, Beale CM, Watts K (2016) Are existing biodiversity conservation strategies appropriate in a changing climate? Biol Conserv 193:17-26. https://doi.org/10.1016/j.biocon.2015.10.024

Özcan MM (2009) Some nutritional characteristics of fruit and oil of walnut (Juglans regia L.) growing in Turkey. Iran J Chem Chem Eng IJCCE 28:57-62

Pearson RG, Dawson TP (2003) Predicting the impacts of climate change on the distribution of species: are bioclimate envelope models useful? Glob Ecol Biogeogr 12:361-371. https://doi.org/10.1046/j. 1466-822X.2003.00042.x

Pearson RG, Thuiller W, Araújo MB, Martinez-Meyer E, Brotons L et al (2006) Model-based uncertainty in species range prediction. J Biogeogr 33:1704-1711. https://doi.org/10.1111/j.1365-2699.2006.01460.x

Peng S, Huang J, Sheehy JE, Laza RC, Visperas RM et al (2004) Rice yields decline with higher night temperature from global warming. Proc Natl Acad Sci 101:9971-9975. https://doi.org/10.1073/pnas.0403720101

Phillips SJ, Anderson RP, Schapire RE (2006) Maximum entropy modeling of species geographic distributions. Ecol Model 190:231-259. https://doi.org/10.1016/j.ecolmodel.2005.03.026 
Phillips SJ, Anderson RP, Dudík M, Schapire RE, Blair ME (2017) Opening the black box: an open-source release of MaxEnt. Ecography 40:887-893. https://doi.org/10.1111/ecog.03049

Pollegioni P, Woeste KE, Chiocchini F, Olimpieri I, Tortolano V et al (2014) Landscape genetics of Persian walnut (Juglans regia L.) across its Asian range. Tree Genet Genomes 10:1027-1043. https://doi.org/10.1007/s11295-014-0740-2

R Core Team (2019) R: A language and environment for statistical computing. Austria, Vienna

Rajora OP, Mosseler A (2001) Challenges and opportunities for conservation of forest genetic resources. Euphytica 118:197-212. https:// doi.org/10.1023/A:1004150525384

Ranjitkar S, Sujakhu NM, Lu Y, Wang Q, Wang M et al (2016) Climate modelling for agroforestry species selection in Yunnan Province, China. Environ Model Softw 75:263-272. https://doi.org/10.1016/ j.envsoft.2015.10.027

Remya K, Ramachandran A, Jayakumar S (2015) Predicting the current and future suitable habitat distribution of Myristica dactyloides Gaertn. using MaxEnt model in the Eastern Ghats, India. Ecol Eng 82:184-188. https://doi.org/10.1016/j.ecoleng.2015.04.053

Ren M-X, Zhang Q-G (2009) The relative generality of plant invasion mechanisms and predicting future invasive plants. Weed Res 49: 449-460. https://doi.org/10.1111/j.1365-3180.2009.00723.x

Riahi K, Rao S, Krey V, Cho C, Chirkov V et al (2011) RCP 8.5-A scenario of comparatively high greenhouse gas emissions. Clim Change 109:33-57. https://doi.org/10.1007/s10584-011-0149-y

Richardson DM, Pyšek P, Rejmánek M, Barbour MG, Panetta FD et al (2000) Naturalization and invasion of alien plants: concepts and definitions. Divers Distrib 6:93-107. https://doi.org/10.1046/j. 1472-4642.2000.00083.x

Rocchini D, Garzón-López CX (2017) Cartograms tool to represent spatial uncertainty in species distribution. Res Ideas Outcomes 3: e12029. https://doi.org/10.3897/rio.3.e12029

Rouget M, Richardson DM, Nel JL, Van Wilgen BW (2002) Commercially important trees as invasive aliens - towards spatially explicit risk assessment at a national scale. Biol Invasions 4:397412. https://doi.org/10.1023/A:1023611713339

Scheffers BR, Meester LD, Bridge TCL, Hoffmann AA, Pandolfi JM et al (2016) The broad footprint of climate change from genes to biomes to people. Science 354:aaf7671. https://doi.org/10.1126/science.aaf7671

Schmidhuber J, Tubiello FN (2007) Global food security under climate change. Proc Natl Acad Sci U S A 104:19703-19708. https://doi. org/10.1073/pnas.0701976104

Schueler S, Falk W, Koskela J, Lefèvre F, Bozzano M et al (2014) Vulnerability of dynamic genetic conservation units of forest trees in Europe to climate change. Glob Change Biol 20:1498-1511. https://doi.org/10.1111/gcb.12476

Seidl R, Schelhaas M-J, Rammer W, Verkerk PJ (2014) Increasing forest disturbances in Europe and their impact on carbon storage. Nat Clim Change 4:806-810. https://doi.org/10.1038/nclimate2318

Spittlehouse D, Stewart RB (2003) Adaptation to climate change in forest management. BC J Ecosyst Manag 4:1-11

Stachowicz JJ, Terwin JR, Whitlatch RB, Osman RW (2002) Linking climate change and biological invasions: ocean warming facilitates nonindigenous species invasions. Proc Natl Acad Sci 99:1549715500. https://doi.org/10.1073/pnas.242437499

Swets JA (1988) Measuring the accuracy of diagnostic systems. Science 240:1285-1293. https://doi.org/10.1126/science.3287615

Sykes MT, Prentice IC (1996) Climate change, tree species distributions and forest dynamics: a case study in the mixed conifer/northern hardwoods zone of northern Europe. Clim Change 34:161-177. https://doi.org/10.1007/BF00224628
Taylor KT, Maxwell BD, McWethy DB, Pauchard A, Nuñez MA et al (2017) Pinus contorta invasions increase wildfire fuel loads and may create a positive feedback with fire. Ecology 98:678-687. https://doi.org/10.1002/ecy.1673

Thuiller W, Richardson DM, Midgley GF (2007) Will climate change promote alien plant invasions? In: Nentwig W (ed) Biological invasions. Springer, Berlin Heidelberg, pp 197-211

Thuiller W, Lavergne S, Roquet C, Boulangeat I, Lafourcade B et al (2011) Consequences of climate change on the tree of life in Europe. Nature 470:531-534. https://doi.org/10.1038/nature09705

Thuiller W, Guéguen M, Renaud J, Karger DN, Zimmermann NE (2019) Uncertainty in ensembles of global biodiversity scenarios. Nat Commun 10:1446. https://doi.org/10.1038/s41467-019-09519-w

Thurm EA, Hernandez L, Baltensweiler A, Ayan S, Rasztovits E et al (2018) Alternative tree species under climate warming in managed European forests. For Ecol Manag 430:485-497. https://doi.org/10. 1016/j.foreco.2018.08.028

Tulloch AIT, Mustin K, Possingham HP, Szabo JK, Wilson KA (2013) To boldly go where no volunteer has gone before: predicting volunteer activity to prioritize surveys at the landscape scale. Divers Distrib 19: 465-480. https://doi.org/10.1111/j.1472-4642.2012.00947.x

van Proosdij ASJ, Sosef MSM, Wieringa JJ, Raes N (2016) Minimum required number of specimen records to develop accurate species distribution models. Ecography 39:542-552. https://doi.org/10.1111/ecog. 01509

van Vuuren DP, Edmonds J, Kainuma M, Riahi K, Thomson A et al (2011) The representative concentration pathways: an overview. Clim Change 109:5-31. https://doi.org/10.1007/s10584-011-0148-z

Vitousek PM, Mooney HA, Lubchenco J, Melillo JM (1997) Human domination of earth's ecosystems. Science 277:494-499. https:// doi.org/10.1126/science.277.5325.494

Walas Ł, Sobierajska K, Ok T, Dönmez AA, Kanoğlu SS et al (2019) Past, present, and future geographic range of an oro-Mediterranean Tertiary relict: the Juniperus drupacea case study. Reg Environ Change 19: 1507-1520. https://doi.org/10.1007/s10113-019-01489-5

Walther GR (2010) Community and ecosystem responses to recent climate change. Philos Trans R Soc B Biol Sci 365:2019-2024. https:/ doi.org/10.1098/rstb.2010.0021

Walther G-R, Roques A, Hulme PE, Sykes MT, Pyšek P et al (2009) Alien species in a warmer world: risks and opportunities. Trends Ecol Evol 24:686-693. https://doi.org/10.1016/j.tree.2009.06.008

Wangen SR, Webster CR (2006) Potential for multiple lag phases during biotic invasions: reconstructing an invasion of the exotic tree Acer platanoides. J Appl Ecol 43:258-268. https://doi.org/10.1111/j. 1365-2664.2006.01138.x

Warton DI, Renner IW, Ramp D (2013) Model-based control of observer bias for the analysis of presence-only data in ecology. PLOS ONE 8: e79168. https://doi.org/10.1371/journal.pone.0079168

Wiens JA, Stralberg D, Jongsomjit D, Howell CA, Snyder MA (2009) Niches, models, and climate change: assessing the assumptions and uncertainties. Proc Natl Acad Sci 106:19729-19736. https://doi.org/ 10.1073/pnas.0901639106

Winter M-B, Wolff B, Gottschling H, Cherubini P (2009) The impact of climate on radial growth and nut production of Persian walnut (Juglans regia L.) in Southern Kyrgyzstan. Eur. J For Res 128: 531. https://doi.org/10.1007/s10342-009-0295-1

Publisher's note Springer Nature remains neutral with regard to jurisdictional claims in published maps and institutional affiliations. 